\title{
Diversity For Nonprofits: Mission Drift Or Mission Fulfillment?
}

\author{
Paul Henry Hawkins, Working Diversity, Inc., USA
}

\begin{abstract}
Nonprofit stewardship imposes two special duties. As stewards of donative resources, nonprofits must fulfill their programmatic mandates. As stewards of public benefit, they must also be responsive to pressing social issues that transcend organizational confines. This paper examines the tension nonprofit leaders encounter when, in response to the latter duty, some stakeholders push for an organizational diversity initiative, while other stakeholders, in response to the former duty, claim organizational diversity initiatives trigger mission drift. Drawing upon an interdisciplinary theoretical palette, this article proposes a conceptual way to reconcile a tightly constructed nonprofit mission with a broader calling to mitigate the degenerative effects of historically embedded identity hierarchies.
\end{abstract}

Keywords: Nonprofit; Mission; Strategic; Social Justice

\section{INTRODUCTION}

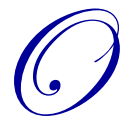

rganizational theorists tell us mission statements help stakeholders focus their actions toward a unifying purpose (Allison \& Kaye, 2005; Kilpatrick \& Silverman, 2005; Nolan, Goodstein, \& Goodstein, 2008; Weiss \& Piderit, 1999). A stated focus is essential, conventional wisdom holds, because organizations of all types face constant pressure to alter what they do and how they do it. Left unchecked, these pressures can produce mission drift, an anchorless state where organizations grasp at passing financial straws and where unplanned outcomes retrospectively become reasons for existence (Bennett \& Savani, 2011; Cochran, David, \& Gibson, 2008; Copestake, 2007; Jones, 2007).

Because nonprofits are typically held to account by multiple constituencies with potentially competing interests (Kearns, 1994; Kim, 2005), those of us in nonprofit leadership positions may be even more susceptible to mission drift than our for-profit counterparts. So following our for-profit counterparts, we have embraced mission statements as a requisite management tool. Accordingly, a new credo has been written into our collective nonprofit gospel - we must hold fast to the letter of our mission statements and vigilantly guard against all manner of encroachment.

Yet for all the management science animating the parade of mission-statement enthusiasts, there are detracting points of view. Barman's historical retrospective (2007, p. 107) suggests that contemporary demands for measurable mission-driven successes have forced nonprofits to abandon the period of innovation and experimentation that was a hallmark of the mid-twentieth century. Barman also suggests that nonprofits are now less able to see and respond to social reality because their view of reality constricts to fit the efficiency constraints of funders (pp. 112-113). This limitation likewise reverberates in Linden's (2010) argument that the dramatic inability of nonprofits to ameliorate contemporary problems is a result of a wholesale movement toward narrow missioncentered management. Linden's (2010) assessment is blunt - "We're trying to address complex, twenty-first-century problems using eighteenth- and nineteenth-century organizational structures and systems" (p. 14). Calling out an ethical shortcoming of this trend, Block (1993) asserts that tight mission-driven management is anathematic to the higher calling of community stewardship that should be the nonprofit sector's guiding ethos:

Stewardship springs from a set of beliefs about reforming organizations which affirms our choice for service over the pursuit of self-interest. When we choose service over self-interest, we say we are willing to be deeply accountable without choosing to control the world around us. (p. 6) 
Such criticism does more than point out the limits of contemporary mission statements; it frames the outline of a mission-statement paradox - the more tightly the mission is envisioned, the less total mission may be accomplished. Rather than impelling a nonprofit to grow horizontally and organically as a community asset, mission statement fealty can limit the organization to the vertical silo walls of core programs. The mission statement and income statement become conjoined tools for building up a narrowly constructed organization where, just as in the for-profit world, revenue-building becomes paramount. In the upshot, cash cow programs get priority, financially marginal activities get cut.

The urgency of community-based themes-stewardship, service, accountability - not only underscores stakeholder dissatisfaction with nonprofits judged to be inculcated with this empire-building mindset, but they also accompany burgeoning calls for us to reorient our nonprofits to thwart the mission statement paradox. Believing the vagaries of government and the egoism of business to have undermined the abilities of those sectors to ameliorate wholesale public problems, there are those who, in a call for the nonprofit sector to stop emulating hard-nosed business models, now hark back to Tocqueville's exhortative view of voluntary associations as the cornerstone of civil society. Hopes are being pinned on the idea that the precipitous growth of the nonprofit sector in recent decades is heralding a new era in which nonprofits will triumph as the lead sector. Summarizing this view, Anheier (2005) writes, "In contrast to the basically quasi-market role nonprofits assume under new public management, the neo-Tocquevillian approach emphasizes their social integrative and participatory function as well as their indirect contributions to community building" (p. 372).

\section{INTERROGATING THE PARADOX}

Invoking Tocquevillian notions of community building sets up a prescient - and ironic- foreground for interrogating the nonprofit mission statement paradox. It is of course well-known that Alexis de Tocqueville, a French politician and historian, traveled the United States in the early 1830s, out of which he published the highly influential Democracy in America. In this wide-ranging ethnography and political treatise, Tocqueville extolled the virtues of American voluntary associations, observing that:

As soon as several of the inhabitants of the United States have taken up an opinion or a feeling that they wish to promote in the world, they look out for mutual assistance; and as soon as they have found each other out, they combine. From that moment they are no longer isolated men, but a power seen from afar, whose actions serve for an example, and whose language is listened to. (p. 597)

In this regard, Tocqueville argued that voluntary associations - the forerunners of today's nonprofitsacted as a mechanism for safeguarding democracy against the destructive tendencies of egoism. It was, by common agreement, prescient.

But the irony, as Smith (1993) picks up, is that Tocqueville could poignantly describe many of the inegalitarian denouements of American democracy upon black slaves and Native Americans - what could rightly be called the most pernicious effects of egoism - and then treat those effects as inconsequential in later discussions of the American polity. The enslaved African and the dispossessed Native American exit the stage when the benefits of voluntary associations upon the attainment of democracy enter in.

Problematic as it is in Tocqueville, it is all the more so in neo-Tocquevillian twenty-first century when the same error is fundamentally reproduced. To speak of a new society - one led by a battalion of mission-driven nonprofits gathering like-minded souls to solve heretofore intractable social problems - becomes little more than an exercise in romantic thinking when there is a fundamental disconnect between the problems we identify and the social inertia driving them. Putting it bluntly, the march of our mission-driven nonprofits is not forward - it is circular; we are caught in a recursive loop whereby the social problems to which we are responding are replicating as fast - or even faster - than the mission-driven organizations we are constructing to mitigate them.

To get some perspective on how nonprofits can get off this hamster wheel, we must first look at the root problem, reconnecting it with the nonprofit sector's calling. The root problem can be succinctly named as our system of ascribing social identity - a system which has spawned hierarchies of social worth. This view takes a cue 
from the best work of social constructionists who, in understanding manifestations of social hierarchy like racism, have coalesced around the core tenet that "the reality of race and racism is not created by an 'essential' nature of persons or 'organic' groups, but by (institutionalized) social practices that implicitly or explicitly have the effect of making 'groups' and 'identities' appear as something essential or given (Elliker, Coetzee, \& Conrad Kotze, 2013, para. 18). Although there are multiple large-scale manifestations of social hierarchy - all deserving attention - given its salience in scholarly literature and public life, we can pick up on this analysis of racism and focus on it as an emblematic form of the social harm that emanates from social hierarchy. Moreover, we can focus on racism by leveraging the preponderant worldview among critical race theorists that, even into the second decade of the twentyfirst century, racism continues to be impelled forward while our actions simultaneously deny its persistence (Ford \& Airhihenbuwa, 2010; Jackson, 2011; Ostertag \& Aramaline, 2011; Williams, 2012).

To take this further, we do well to recognize that at the center of contemporary American racial discourse is a collective, selective memory. We recall the seemingly breathtaking advances made between 1954 and 1968 . In our minds, we form out of those years an embrasure that opened when Brown was handed down from the U.S. Supreme Court. Then we close it upon that fateful April when Martin Luther King, Jr. was assassinated and Congress passed the era's last major piece of federal legislation - the Fair Housing Act. In the wake of those fourteen years, for all the joy and pain they triggered, we inhale as we look back and fancy that a great and scrappy generation had at last brought to fruition the kernel of Justice Harlan's famous Plessy (1896) dissent. Then we exhale, relieved that our post-civil rights social order upholds the idea that, as Harlan wrote, "Our Constitution is color-blind and neither knows nor tolerates classes among citizens."

But then a thoughtful few courageously pinpoint an alternative to this narrative's closed-circuit nature. Farley, for instance (2002, p. 121), unmasks the disquieting ruination that "Our civil-rights statutes serve mainly to delegitimize any claims that discrimination continues. This last task they do well - so well that discrimination today is spoken of only as a vestigial remnant of yesterday, not as the very pulse of morning." What Farley and his compatriots in the critical race theory camp have been trying to tell us over the past thirty-odd years is that after we peel back the opaque shrink wrap on our contemporary fantasies about having passed through the gritty nadir of racism to the wonders of a post-racial era, we are left with the reality of what Bell (1992) identifies as the permanence of racism. Contradicting the popular narrative, Bell tells us that "Even those herculean efforts we hail as successful will produce no more than temporary 'peaks of progress,' short-lived victories that slide into irrelevance as racial patterns adapt in ways that maintain white dominance" (p. 12). Indeed, the present mainstream of American racial discourse, anchored in tropes about how Barack Obama's election solidified the new post-racial norm, is yet another sleight-of-hand maneuver that instructs us to abandon old-school resistance to racism under the gleeful supposition that white dominance is dead. Cho (2009, p. 1641) hits the nail on the head: "Post-racialism insulates white normativity from criticism and ultimately serves to redeem the full value of whiteness infringed from its negative associations with the pre-civil rights, Jim Crow era."

To reorient ourselves against the post-racial fantasy is to counteract our passive felicity for Justice Harlan's notion of a color-blind Constitution. It is to recall that the idea of permanent white "dominance" did not originate with Bell and other critical race theorists, but was named by - even extolled by - Harlan himself. To reorient ourselves against the post-racial fantasy is to stop looking at the civil rights era as a fulfillment of an ideal, but as a fragile generational gift that morally obligates us to present-day collective action. It is to choose ways of organizing that respect that fragility by responding to the permanence of racism with a permanence of resistance. It is to choose resistance to racism as an expression of a collective faith - one that understands that present-day efforts are an essential part of a long stream of multi-generational contributions.

In light of this reorientation, the mission statement paradox raises tough questions. When we accept that the legacy of racial inequity is imbedded in the marrow of our contemporary social order, can we still declare that the only way to organize nonprofits is through strict adherence to tightly-knotted nonprofit mission statements? Can we morally defend narrow organizational proscriptions after we realize that the only sustainable way to build a public health clinic in Newark, prevent hunger in the Mississippi Delta, disrupt illiteracy in Grand Forks, reclaim an urban garden out of a Pittsburgh brownfield, foster a spiritual awakening in Riverside, cultivate an intergenerational appreciation for baroque music in Boston, or achieve any other long-term public good, is through a consonant redress of this legacy? If, as nonprofit stakeholders, we insist we are unable to palliate the recalcitrant effects of 
racism and its oppressive cousins because good management practice requires us to exclusively focus on specific, measurable, achievable, mission statement-driven outcomes, then how do we square that narrow imperative against the unimpeachable imperative for wholesale social change?

\section{DIVERSITY AS FENCE SITTING}

Somewhere in our collective consciousness, we realize that we cannot continue to ignore the juggernaut of oppression that stampedes atop lives and grinds down souls. Somewhere we realize that those lives, those souls, belong to our sisters and brothers, as our very selves. Based on these realizations, we develop an emotional disposition that calls for social justice, but since we are also tepid about straying outside the seemingly verdant patch of grass staked out by our organizational mission, neither are we eager to jump out in front of the juggernaut; so we fence sit, like a kid in summer with a blade of grass between her teeth, plucked from the juggernaut's swath. It is bitter. It is sweet.

It is what we in the nonprofit realm call diversity, and it is how we practice it. Like that blade of grass, we pull out a thin strand from our organizational budget and sheepishly relinquish it so we can purchase a book for our nonprofit management library, something with the word "multicultural" in the title, or we tack up a poster in February for Black History Month, another in March for Women's History Month, followed by Asian-Pacific American Heritage Month, Hispanic History Month, LGBT History Month, Native American Heritage Month, and so on. If we are a bit more ambitious, we choose from among a plethora of event-driven options - the annual cultural awareness day, the social justice awards breakfast, the community roundtable discussion, the academic conference, the luncheon guest speaker. Perhaps, if stakeholder voices are loud enough, we organize the diversity committee, mandate the sensitivity training program, write up the inclusiveness policy manual, or add diversity management to an employee's responsibilities.

In doing all these things, we strike an implicit bargain. We trade a piece of our organizational resources for the peace of mind that we have done our due diversity diligence. Researchers have dubbed this effect "moral credentialing" (Brown et al., 2011; Monin \& Miller, 2001) and at its center lies a subconscious bait-and-switch. A discrete egalitarian act psychologically substitutes for sustained effort; a momentary good deed for racial justice becomes a proxy for a fixed identity as a racial justice do-gooder.

Brown et al. (2011) demonstrate that moral credentialing is problematic because, rather than propelling substantive change, it can lead to recidivism. When an individual fastens on a self-credentialed badge, there is little impetus to grow. Without growth, the hegemony of social stratification is no longer resisted. Without resistance, old habits creep back in. The old habit is to continually ignore the disparities racism imparts.

Logic dictates the same devolutionary tendency that applies to organizations. Butterfield, Treviño, and Weaver's (2000) research demonstrates that organizations adopt an ethical personality based on a process of intraorganizational socialization; so even if some people in the organization individually express a desire to create a tangible, sustainable drive toward justice-centered diversity, when doing so abrades the central organizational ethic, those change-minded individuals are socialized back to the center of gravity. They face pressure to accept the organizational ethos instead of encouragement to develop it. Against this backdrop, it is not surprising that many researchers have documented cases of organizational failures to translate a moral imperative for social justice into a tactile organizational development program (Harrison \& Klein, 2007; Jayne \& Dipboye, 2004; Pitts, 2007). The talk fails to become the walk.

At the heart of the moral credentialing problem, therefore, is the allure of comfortable illusions, and one illusion begets others - we mistakenly believe that whatever resources our organization devotes to long-term social inequities will siphon resources away from our organizational mission, just as we mistakenly believe that the small expenditures of time and resources we give to promote diversity will, in turn, vouchsafe our personal and organizational moral credentials. Constrained by these illusions, we struggle to find a midpoint. We cede just enough resources to shore up our self-perception without inflicting what we perceive to be consequential damage to our cash flow. In this half-hearted space, we remain stuck on the fence where our efforts are little more than feelgood symbolism. 
Even worse, because the inequities imbedded in society unavoidably seep into our organizations (Brief et al., 1997; Freeman, 1975), our fence-sitting keeps our organizations locked in a replicative pattern. Jones (1997, p. 472) describes institutional racism as an interlinear set of persistent organizational policies and practices that subtly create disparate race-based outcomes. To wit, the harm is not merely in the outcomes, but in the persistence ingrained in the organization's way of doing business, the pattern repeats from year to year, decade to decade. Even while we imagine with disdain those circles of hooded bigots howling in the moonlit glow of burning crosses, it is the subtle replicative patterns imbedded beneath our august organizational surfaces that keep racism and its swarthy cousins ensconced in quiet permanence.

While it may seem that promoting diversity artfully mitigates racism's institutional effects, in reality it rarely does. Organizational diversity programs generally do not dislodge institutional racism because they focus on changing individual attitudes or behaviors and not on changing the organization's culture or business practice (Trenerry \& Paradies, 2012, p. 12). So, even as we perceive ourselves to be working on a solution, because our piecemeal diversity programs do not change our organizational patterns, our organizations remain part of the problem. In the upshot, our fence-sitting not only undermines a justice-centered pursuit of organizational diversity, we end up ameliorating the very inequities at the heart of our social ills.

\section{DIVERSITY AS FENCE JUMPING}

The good news is that we can choose a different way. We need not settle for the implicit bargain and we need not remain stuck on the fence, gazing passively at the outside world. Despite the permanence of racism and other systemic oppressions, we need not be immobilized by the apparent conundrum between following a welldefined nonprofit mission and responding to a broadcast call for social change. Like all those black and white photographs of Jim Crow, despite the immutable suffering, there is an illuminating beauty in their contrast. For in the conjoined grains of light and dark, we can discern the outline of a promising alternative to the conundrum. Instead of regarding long-term social inequities as capacity-draining obstacles, we can see them as capacity-building opportunities. We can rework the paradigm. We can see redressing social inequities as an investment - an investment that will yield a transformative payoff.

Shifting the paradigm this way raises a joyous question about how, exactly, nonprofits can pull it off. How can we square an unbridled commitment to justice-based diversity with the hard tacks of operational realities? How can we ensure that our diversity initiatives result in mission fulfillment instead of mission drift?

The first step is belief. We still need an emotional commitment to social justice in order to meaningfully advance organizational diversity, but belief is greater than emotional commitment; belief is an empowering sense, an unshakable perception that our organizations can become vehicles for creating a just society without drifting from a coherent service niche. Once we embrace this belief, we have a sharper perspective from which we can shed the conundrum.

The second step is to build our capacity for bringing our vision to fruition. Capacity-building is not unfamiliar terrain for nonprofits. As Newborn (2008, p. 23) indicates, it has now become expected that nonprofits will critically examine how they need to change and go about acquiring the means to implement their selfreinvention. The question, then, is how to migrate between belief that an organization can serve its well-defined mission and build the capacity to act as a catalyst for social justice.

Acting as a catalyst for social justice may seem like a tall order, but fortunately the same erudite camp of business scholars that made mission statements popular has also given us an apt capacity-building tool. Thanks to the articulation of Hamel and Prahalad (1989), it is known as strategic intent. If mission statements are the equivalent of sewing scissors - a tool for us to neatly cut out a rote organizational pattern - then strategic intent is the equivalent of a buzz saw - the pattern is not paramount; fulfilling a vision is. Everything standing in the way of the vision is dead wood.

Consider Hamel and Prahalad's (1989) analysis of the for-profit world. In studying why some major global firms had fallen prey to upstart competitors, they found that adopting a strategic intent was a definitive feature of the rising multinationals: 
Companies that have risen to global leadership over the past 20 years invariably began with ambitions that were out of all proportion to their resources and capabilities, but they created an obsession with winning at all levels of the organization and then sustained that obsession over the 10- to 20-year quest for global leadership. We term this obsession "strategic intent." (p. 64)

Just as nonprofits took a cue from their for-profit counterparts and embraced the idea that mission statements are a tactile way to orient organizational stakeholders toward a common purpose, nonprofits can embrace strategic intent as a way of leaping beyond the confines of insipid mission statement construction. They can follow the example of multinational corporations that have shifted their perspective from merely defining and refining their product or service line. Quite the contrary, those that have become ultra-successful competitors used strategic intent to strike out on a path toward global ascension.

Granted, we generally do not want our nonprofits to become imperial economic powerhouses, but by thinking like the utility-minded managers guiding profitable multinationals, we can decide that becoming the vanguard social justice engine in our service arena will be our nonprofit obsession. We can decide that in the midst of pursuing that obsession, we will likewise become excellent purveyors of mission-defined nonprofit services. In this paradigmatic inversion, it is our obsession which defines our services, not the other way around.

Of course, excellence requires more than intent. Yet as Hamel and Prahalad (1989) describe, only a few key organizational attributes must be developed to secure its foundation. A nonprofit organization with a shared understanding of social justice, with stakeholders who are motivated to creating the reality that understanding imparts, and with a process that invites everyone to participate in building that reality, is well positioned to catapult itself to a new level of effectiveness. The only additional requirement is an ongoing communications process that ensures everyone understands how change is occurring and how resources will be allocated to ensure the vision comes to fruition.

\section{BUILDING STRATEGIC INTENT THROUGH DIALOGUE}

Adopting a mission statement is often a perfunctory exercise; as Cochran, David, and Gibson (2008) state, "it can be accomplished 'in house' with only a minimum amount of time and resources" (p. 37). In for-profit and nonprofit enterprises alike, crafting a powerful strategic intent requires more than a committee report and a board resolution. It requires dialogue about the organizational soul.

Unlike conversations, which may be one-way impositions, true dialogue is marked by an exchange of ideas. All stakeholders have a joint investment in speaking, listening, and reflecting (April, 1999). Constructive dialogue, like a strong organization, develops thus. It develops through thoughtful steps. Via an allegiance to mutuality, conversations lead to convergences, and core ideas gain steam. There is momentum. Through dialogue, nonprofit stakeholders discover a common truth and a way of working on that truth together.

Accordingly, the transformative payoff that comes from incorporating social justice into the bedrock of a strategic intent does not happen as a result of top-down edicts or bottom-up demands; it emerges from traversing an inherently non-hierarchical footpath. This is the essence of shared leadership, which contrasts against the individual-as-leader model that remains doggedly at the core of Western organizational theory. When a single individual is dubbed the leader, that individual is deemed responsible for motivating a subordinate collective and members of the collective are expected to conform their actions to the leader's commands. Under shared leadership, which researchers have found to increase collective efficacy (Solansky, 2008; Ensley, Pearson, \& Pearce, 2003; O'Toole, Galbraith, \& Lawler, 2002), a greater synergy of motivations is let loose. Motivation for achieving the organization's strategic intent remains infectious because stakeholders keep reinfecting each other with new strains of the same inspirational bug. Indeed, in the midst of the for-profit sector's reluctance to embrace shared leadership, the prospect of nonprofits inverting that reluctance in pursuit of justice promises to be the lever that catapults the sector into the vanguard position that social visionaries have been long aching for.

Such a large scale transformation also seems possible for multiple nonprofits because among for-profit organizations, strategic intent is positioned as a formula for gaining global ascendancy against one's international 
competitors (Hamel \& Prahalad, 1989). The for-profit paradigm lauds dominance in a zero-sum game. Among nonprofits, however, this goal is, or at least ought to be, flipped. Nonprofit organizations are not designed to compete against each other for market share as the penultimate reward en route to maximizing profits. To the extent nonprofits compete, they do so to fulfill the most pressing public needs in the most efficient ways possible (Brooks, 2005), hence a nonprofit that uses constructive dialogue to develop a shared social justice framework and then uses that framework to derive a strategic intent, positions itself to accomplish an end for which the profit-maximizing private enterprise is not designed. Freed from profit maximization, the nonprofit can address society's most pressing collective needs. In doing so, that organization rises to the higher echelon of nonprofits that do not merely serve a mission but create the kind of transformative change needed to dislodge persistent inequities.

\section{CONCLUSION}

When our nonprofits succeed, they become more than organizations; they become legacies, but the social inequities at the heart of our public needs are also legacies which invariably meet up with and abrade the better legacies we would have our organizations impart. To forestall this abrasion, to forestall the legacy of social inequity, and to build a legacy of social justice, we can choose a different trajectory for our nonprofits. We can see social justice as the basis for a new kind of diversity and create the kind of dialogues we need to transform our organizations from those guided by rote adherence to bland mission statements into those guided by far-reaching strategic intent. In the process of pursuing this new diversity praxis, we can transform our nonprofits as we transform ourselves. By molding justice into the rubber of our organizational linings, we can raft a new future.

\section{AUTHOR INFORMATION}

Paul Henry Hawkins, PhD, PMP, is Board Chair of Working Diversity, Inc., a nonprofit organization that matches volunteer mentors with emerging diversity and inclusion change agents. He is also a regular presenter on diversity topics at leading academic and trade conferences. E-mail: info@ workingdiversity.org

\section{REFERENCES}

1. Allison, M., \& Kaye, J. (2005). Strategic planning for nonprofit organizations: A practical guide and workbook (2nd ed.). Hoboken, NJ: John Wiley \& Sons.

2. Anheier, H. K. (2005). Nonprofit organizations: Theory, management, policy. London, UK: Routledge.

3. April, K. A. (1999). Leading through communication, conversation and dialogue. Leadership \& Organization Development Journal, 20(5), 231-241.

4. Barman, E. (2007). What is the bottom line for nonprofit organizations? A history of measurement in the British voluntary sector. Voluntas, 18(2), 101-115. doi:10.1007/s1 1266-007-9039-3.

5. Bell, D. (1992). Faces at the bottom of the well: The permanence of racism. New York, NY: Basic Books.

6. Bennett, R., \& Savani, S. (2011). Surviving mission drift: How charities can turn dependence on government contract funding to their own advantage. Nonprofit Management \& Leadership, 22(2), 217231. doi: $10.1002 / \mathrm{nml} .20050$

7. Block, P. (1993). Stewardship: Choosing service over self-interest. San Francisco, CA: Berrett-Koehler Publishers.

8. $\quad$ Brief, A. P., Buttram, R. T., Reizenstein, R. M., Pugh, S. D., Callahan, J. D., McCline, R. L., \& Vaslow, J. B. (1997). Beyond good intentions: The next steps toward racial equality in the American workplace. Academy of Management Executive, 11(4), 59-72. doi:10.5465/AME.1997.9712024839

9. Brooks, A. C. (2005). What do nonprofit organizations seek? (And why should policymakers care?). Journal of Policy Analysis and Management, 24(3), 543-558. doi:10.2307/30164063

10. Brown, R. P., Tamborski, M., Wang, X., Barnes, C. D., Mumford, M. D., Connelly, S., \& Devenport, L. D. (2011). Moral credentialing and the rationalization of misconduct. Ethics and Behavior, 21(1), 1-12. doi:10.1080/10508422.2011.537566

11. Butterfield, K. D., Treviño, L. K., \& Weaver, G. R. (2000). Moral awareness in business organizations: Influences of issue-related and social context factors. Human Relations, 53(7), 981-1018.

12. Cho, S. (2009). Post-racialism. Iowa Law Review, 94(5), 1589-1645. 
13. Cochran, D. S., David, F. R., \& Gibson, C. K. (2008). A framework for developing an effective mission statement. Journal of Business Strategies, 25(2), 27-39.

14. Copestake, J. (2007). Mission drift-Understand it, avoid it. ESR Review, 9(2), 20-25. Retrieved from http://marriottschool.byu.edu/esrreview/view_archive_issue.cfm?issue=fall07

15. Elliker, F., Coetzee, J. K., \& Conrad Kotze, P. (2013). On the interpretive work of reconstructing discourses and their local contexts. Forum: Qualitative Social Research, 14(3), 1-31.

16. Ensley, M. D., Pearson, A., \& Pearce, C. L. (2003). Top management team process, shared leadership, and new venture performance: A theoretical model and research agenda. Human Research Management Review, 13, 329-346.

17. Farley, A. P. (2002). The poetics of colorlined space. In F. Valdes, J. McCristal Culp, and A. P. Harris (Eds.), Crossroads, directions, and a new critical race theory (pp. 97-158). Philadelphia, PA: Temple University Press.

18. Ford, C. L., \& Airhihenbuwa, C. O. (2010). Critical race theory, race equity, and public health: Toward antiracism praxis. American Journal of Public Health, 100(S1), S30-S35. doi: 10.2105/AJPH.2009.171058

19. Freeman, J. (1975). Political organization in the feminist movement. Acta Sociologica, 18(2/3), 222-244. Retrieved from http://www.jstor.org/stable/4194062

20. Hamel, G., \& Prahalad, C. K. (1989). Strategic intent. Harvard Business Review, 67(2), 63-76.

21. Harrison, D. A., \& Klein, K. J. (2007). What's the difference? Diversity constructs as separation, variety, or disparity in organizations. Academy of Management Review, 32(4), 1199-1228. doi:10.5465/AMR.2007.26586096

22. Jackson, T. A. (2011). Which interests are served by the principle of interest convergence? Whiteness, collective trauma, and the case for anti-racism. Race, Ethnicity \& Education, 14(4), 435-459. doi: 10.1080/13613324.2010.548375

23. Jayne, M. E. A., \& Dipboye, R. L. (2004). Leveraging diversity to improve business performance: Research findings and recommendations for organizations. Human Resource Management, 43(4), 409-424. doi:10.1002/hrm.20033

24. Jones, M. B. (2007). The multiple sources of mission drift. Nonprofit and Voluntary Sector Quarterly, 36(2), 299-307. doi:10.1177/0899764007300385

25. Kearns, K. P. (1994). The strategic management of accountability in nonprofit organizations: An analytical framework. Public Administration Review, 54(2), 185-192. Retrieved from http://www.jstor.org/stable/ 976528

26. Kilpatrick, A., \& Silverman L. (2005). The power of vision. Strategy \& Leadership, 33(2), 24-26. doi:10.1108/10878570510586810

27. Kim, S. (2005). Balancing competing accountability requirements: Challenges in performance improvement of the nonprofit human services agency. Public Performance \& Management Review, 29(2), 145-163. Retrieved from http://www.jstor.org/stable/20447584.

28. Linden, R. M. (2010). Leading across boundaries: Creating collaborative agencies in a networked world. San Francisco, CA: Jossey-Bass.

29. Monin, B., \& Miller, D. T. (2001). Moral credentials and the expression of prejudice. Journal of Personality and Social Psychology, 81, 33-43.

30. Newborn, T. (2008). Creating nonprofit excellence through capacity building. Nonprofit World, $26(2), 23$.

31. Nolan, T. M., Goodstein, L. D., \& Goodstein, J. (2008). Applied strategic planning: An introduction (2 ed.). San Francisco, CA: Pfeiffer.

32. Ostertag, S. F., \& Armaline, W. T. (2011). Image isn't everything: Contemporary systemic racism and antiracism in the age of Obama. Humanity \& Society, 35(3), 261-289.

33. O'Toole, J., Galbraith, J., \& Lawler, III, E. E. (2002). When two (or more) heads are better than one: The promise and pitfalls of shared leadership. California Management Review, 44(4), 65-83.

34. Pitts, D. W. (2007). Implementation of diversity management programs in public organizations: Lessons from policy implementation research. International Journal of Public Administration, 30, 1573-1590. doi:10.1080/01900690701230192

35. Plessy v. Ferguson, 163 U.S. 537, 559 (1896). (Harlan, J., dissenting).

36. Smith, R. M. (1993). Beyond Tocqueville, Myrdal and Hartz: The multiple traditions in America. American Political Science Review, 87(3), 549-566. Retrieved from http://www.jstor.org/stable/2938735 
37. Solansky, S. T. (2008). Leadership style and team processes in self-managed teams. Journal of Leadership \& Organizational Studies, 14(4), 332-341.

38. Tocqueville, A. (1901). Democracy in America - Vol. 2 (H. Reeve, Trans.). New York, NY: D. Appleton.

39. Trenerry, B., \& Paradies, Y. (2012). Organizational assessment: An overlooked approach to managing diversity and addressing racism in the workplace. Journal of Diversity Management, 7(1), 11-26.

40. Weiss, J. A., \& Piderit, S. K. (1999). The value of mission statements in public agencies. Journal of Public Administration Research and Theory, 9(2), 193-223. Retrieved from http://www.jstor.org/stable/1181805

41. Williams, G. L. (2012). Embracing racism: Understanding its pervasiveness and persistence. Multicultural Education, 20(1), 42-44. 


\section{NOTES}

